\title{
New Urbanism and Chicago
}

\author{
N. M. Truog \\ Sustainable Development, LaSalle Bank/ABN AMRO, USA
}

\begin{abstract}
Urban centers throughout the world are places of commerce, tourism, education, and, most importantly, a residence for many. In a time when urban development and re-development are on the minds of government and citizens alike, it is worthwhile considering how important the principles of New Urbanism are to our modern-day cities, specifically Chicago, Illinois, USA.

Keywords: sustainable development, new urbanism, smart growth, Chicago, sustainability, greening, community development.
\end{abstract}

\section{Introduction}

New Urbanism is defined on the website www.newurbanism.org as "Giving more people more choices about where and how they want to live;" and the movement entails creating a better future for all. It is a way to reform the design of the existing environment, and raise the quality of life for all. It looks at both how to fix existing cities and how to create compact new towns and villages.

Chicago is a city in a constant state of development. The leadership of Chicago is committed to developing Chicago in a manner that will help Mayor Daley achieve his sustainability goal of making Chicago the greenest city in the nation, if not the world. The greening of Chicago could be achieved by following the principles of New Urbanism, as one of these principles is sustainability, and focuses on the environment within a community.

New Urbanism presents an opportunity for cities to improve the quality of life for residents, help the environment, create more livable space, and improve how space is used from a single building to an entire community. This paper will explore the principles of New Urbanism and the principles that are applied in Chicago. Edmund Bacon, an urban planner whose vision shaped current-day Philadelphia, said, "The building of cities is one of man's greatest achievements" 
(Ed Bacon Foundation [1]). New Urbanism can ensure that these achievements are sustainable and livable.

\section{Principles of New Urbanism}

New Urbanism consists of ten principles which can be followed to achieve goals of making cities more livable and giving people more choices about where and how they want to live. These can be applied to a project that focuses on building a new school, one that looks at how to re-build an urban center, or the development of a housing subdivision.

\subsection{Walkability}

Walkability calls for having amenities within a 10-minute walk of home and work and pedestrian friendly street design. Many of Chicago's residents cannot imagine living in a space where you cannot walk to the dry cleaner or grocery store. Residents of Los Angeles, though, only know a way of life where getting from point $A$ to point $B$ includes a vehicle. Walkability of an area ensures that residents are pedestrians of an area and more people and fewer cars use the space. In a time when gas prices are at record highs across the country, walkability is very valuable. Pedestrian-friendly communities also offer more opportunities to get to know ones neighbors. In Chicago, for example, popular places for socializing include the farmer's markets. The markets exist throughout the city because there is land to hold them on, and residents want this opportunity in their neighborhoods throughout the summer and fall seasons. The majority of the markets are in walkable neighborhoods, and people come by foot to buy produce. Chicago is an example of an urban center fortunate to have green space set aside for use by people.

The Chicago Tribune recently conducted a poll and wrote a special report to name Chicago's seven wonders. The \#1 'wonder' that Chicago was defined by is the lakefront. One poll respondent from New York City wrote that he has never seen such a beautiful lakefront, but also he has never been in an urban city where tree-lined streets and sidewalks were the norm. Residents throughout most Chicago neighborhoods are lucky to have sidewalks that give them the opportunity to walk. However, in some neighborhoods the environment is not conducive to walking due to concerns regarding traffic \& general safety. The walkability principle of New Urbanism works to ensure that access and safety are the standards in neighborhoods; residents do not have to feel lucky to have a sidewalk, but rather expect that walkability is part of everyday life.

\subsection{Connectivity}

Connectivity refers to creating interconnected streets that disperse traffic and ease walking. This includes use of narrow streets, boulevards, and alleys, and it creates a network of streets that are pedestrian-friendly. Eased walking means that people have a safe distance between where they are walking and where cars are, and that more direct walking routes are created. Connectivity also refers to 
the "directness of links and the density of connections in a path or road network" (Victoria Transport Policy Institute [2]). As the connectivity of an area increases, travel distances decrease, and options for getting places increase allowing more direct travel between destinations. Chicago is a good example of a connected network of streets. The great Chicago urban planners (Daniel Burnham, for example), created the city on a grid of north/south, east/west streets.

\subsection{Mixed-use and diversity}

Mixed-use developments include a mixture of shops, offices, apartments, and homes in one development site. Mixed-use buildings are more common in Europe than in the United States due to U.S. zoning laws which deter mixed-use development. Nonetheless, developers and investors find value in the fact that a mixed-use development's success does not hinge upon one factor, but instead, has an opportunity for success within the commercial and residential aspects of a building.

Diversity in New Urbanism refers to creating space that incorporates and is welcoming to a diverse population - recognizing age, culture, race, and social "class" as the factors for diversity. This principle calls for a range of housing opportunities as well as uses within each neighborhood. It advocates mixing income groups in what some may call a new way of thinking about communities.

Mixed-use development is a principle that is rarely realized in practice, but is a central tenet of New Urbanism, and it sets a direction quite different from most sprawl and urban renewal programs. Diversity in New Urbanism works to create space where low and moderate income individuals and families can acquire affordable housing amongst market-price housing, and where a mixed population lives side-by-side.

\subsection{Mixed housing}

What may be right for some is not always right for all, and neighborhoods with mixed housing options can attract a more diverse resident population. New Urbanism calls for a range of the type, size and price of housing within close proximity and it encourages developers to create and provide various housing designs.

\subsection{Quality architecture and urban design}

This New Urbanism principle emphasizes beauty, aesthetics, human comfort, and creating a sense of place. Particular attention is given to the placement of civic-use space and sites within a community. New Urbanism also touts that human scale architecture and beautiful surroundings will nourish the human spirit. More green space can be created and citizens' access to culture is increased. 


\subsection{Traditional neighborhood structure}

In a traditional neighborhood structure, it is physically possible to walk to stores, schools, and businesses. The New Urbanism neighborhood structure puts public space at the center of a town or neighborhood, includes public open-space, and density is characteristic of the center of city space.

\subsection{Increased density}

This principle is closely aligned with number 6 , as a critical feature of traditional neighborhood structure. Increased density suggests locating more residences and businesses closer together because money will stay in the city or neighborhood where businesses and people are concentrated.

\subsection{Smart transportation}

On an average workday in Chicago, nearly 1.5 million rides are taken on Chicago Transit Authority (CTA) train and bus routes (Chicago Transit Authority Online [3]). New Urbanism promotes a network of high-quality trains that connect cities, towns, and neighborhoods and increased use of bicycles and walking as daily transportation.

\subsection{Sustainability}

Sustainability means how resources are used today so as not to deplete or permanently damage them for the future. More U.S. corporations and households are recognizing the importance of conducting business and life in a sustainable manner.

New Urbanism defines sustainability as developing land and space with a minimal environmental impact, creating energy efficiency, using less fuel, producing more goods in a local environment (local business and agriculture), and more walking \& less driving.

\subsection{Quality of life}

The final principle - quality of life - envelopes the preceding nine principles into a tenth that says that all of the principles create a "high quality of life worth living" and places that "enrich, uplift, and inspire the human spirit" (New Urbanism Online [4]).

\section{Pros and cons of New Urbanism}

New Urbanism, at times referred to as 'smart growth', is a movement working to improve quality of life. The Congress for the New Urbanism (CNU) is a Chicago-based non-profit that was founded in 1993, and is currently run by John Norquist (former mayor of Milwaukee, Wisconsin). The organization works with architects, developers, and planners to implement the New Urbanism 
principles, and has over 2,000 members throughout the world. It was founded to "restore existing urban centers and towns within coherent metropolitan regions, reconfigure the sprawling suburbs into communities of real neighborhoods and diverse districts, conserve natural environments and preserve our built legacy" (Norquist [5]).

\subsection{New Urbanism critics}

Not everyone is amenable to living in a downtown center, an urban neighborhood, or a mixed-use building. There are scores of people who enjoy suburban living and the auto-centric way of life. Those choosing to live in the suburbs may feel that the type of space and amenities offered in their location are better for raising a family, and offer a more "relaxed" way of life.

New Urbanism design and development encourages the creation of density of people and businesses. But linked with the density principle is the assumed result of more walking and less driving. If driving is not reduced, then the concentration of autos can lead to a greater amount of air pollution. Cars idling while drivers wait for traffic lights to change to only move a block or two can wreak havoc on air quality. If anti-sprawl projects increase gridlock in a densely packed urban core, they may have harmful effects on the environment.

\subsection{Rebuttal}

Evidence suggests that a growing numbers of cities, developers, business owners, and government leaders do see the value of New Urbanism and are becoming more open to implementing the principles within their neighborhoods. Norquist says that "cities have always been the source of wealth and culture" and that the only way to save them, is if "people value them" (City Journal [6]). He takes the position that the only way to restore civility and culture in America is to rebuild cities. Great cultures have come out of cities such as Rome \& Athens and one could argue that Chicago is a more current-day example of an evolving culture that developed (and continues to develop) because of its urban environment.

\section{Chicago and New Urbanism}

Mayor Daley has vowed to make Chicago the greenest city in the nation, if not the world. Prior to the Richard M. Daley era, Chicago grew out of the success of manufacturing with production and jobs the key concerns. Protecting the City's natural resources was not on the agenda of most of the businessmen/manufacturers of the late 1800s, like Cyrus McCormick or Philip Armour. This was a time of profits before protection. Chicago was fortunate, though, that other non-manufacturing business people, such as Aaron Montgomery Ward and Daniel Burnham, also made Chicago home.

Montgomery Ward made his money with his mail-order catalog business, but he also helped save Chicago's Lake Michigan Shores. Ward's office was located across from property that was unsightly and full of abandoned junk. Ward 
fought to not have Marshall Field's new museum of natural history placed on the property. In 1909, all of Ward's work toward saving the lakefront was rewarded when the Supreme Court of Illinois judged that the lakefront would remain a public space.

Architect Daniel Burnham was a driving force behind the City Beautiful movement during the Progressive Era. Burnham believed that one should "make no little plans" as they would not be inspiring. Burnham left his mark on many cities, and a couple of his local accomplishments included building the White City for the 1893 World's Columbian Exposition and the Chicago Plan. In his Chicago plan, Burnham called for replacing crowded streets with landscaped boulevards, a park that would stretch along the shore of Lake Michigan, and for the relocation of the city's railroad lines and depots. Journalist Lincoln Steffens wrote in The Shame of the Cities (published in 1904) that Chicago was "First in violence, deepest in dirt; loud, lawless, unlovely, ill smelling..." (Spinney [7]). It was men like Montgomery Ward and Burnham who helped begin Chicago's climb out of the dirt and their legacy is still visible today.

Hence, Richard M. Daley did not invent this commitment to greenness and open space in Chicago; he had a great base to build upon. Unlike many of the country's large cities, the majority of Chicago's waterfront property was preserved as beach and public parks. But equally important, there are nearly 600 parks within the city limits and thousands of trees act as a canopy over the city.

Nevertheless, he had new reasons to pursue greenness and beautification. By the 1980s, sections of the city had devolved into an industrial wasteland with industrial environmental clean-up sites and abandoned factories that once provided thousands of jobs. Through the 1990s Chicago began to experience what shaped up to be one of the most spectacular urban renaissances in modern history. This renaissance is equated to such things as urban and suburban population growth, immigration, and an environmentally-pleasant urban habitat.

In 1989, newly elected Mayor Daley was trying to figure out how to bring Chicago out of the post-industrial "slag heap" and decided that planting trees was the best way to do this. Since 1989, the city has spent $\$ 5.2$ billion improving Chicago's walkways, streets, parks, and neighborhoods.

Mayor Daley developed a new industry to replace the old. Much has been written about the mayor's "obsession" with tourism as the industry of the $21^{\text {st }}$ century. In the summer of 2005, Daley announced that he would consider bidding to host the 2016 summer Olympics in Chicago. Such an event would cost the city a great amount of money to prepare for the Olympics, however, the tourist, athlete, and sponsor dollars flooding the city economy could be worth the expense. A more recent sporting event that brought dollars to Chicago was the White Sox victory in the Major League Baseball World Series. Mayor Daley says he is a Sox fan because he grew up in Bridgeport (Southside Chicago), however, the green brought in by the "White", could be the reason he is supporting the team who brought attention to the Second City. These other types of income are examples of business development that the Mayor may focus his attention on when other businesses are not flourishing. 


\section{New Urbanism in Chicago}

One cannot travel through Chicago and see signs pointing out the New Urbanism principles present; however, the principles do exist.

\subsection{Transportation}

Smart Transportation is one of the New Urbanism principles that is key to connecting cities and towns and neighborhoods. Walking as daily transportation is ideal in a New Urbanist environment, however, cannot be a reality in all places and public transportation is key to keeping Chicago moving. For those who have to depend on their car it is no longer limited to Chicago's expressways. Many neighborhood streets are becoming thoroughfares and New Urbanism looks to eliminate this congestion and provide better transportation alternatives.

New Urbanists will be the first to tell anyone who will listen that highways destroy cities. In 1957, U.S. Congress passed the Interstate Highway Act (signed by President Eisenhower). The purpose of the act was to augment state highways with a network of limited-access highways. A federal gas tax paid for $90 \%$ of highway construction and maintenance costs, and states paid the remaining $10 \%$. The construction of highways has cut through urban areas and extended the reach of suburbs while using federal funding that is taken away from urban transportation systems.

The reality is that without motorways, people would not be as connected as they are today with access to existing highways. The problem that New Urbanists point out is that on most highways throughout the U.S., a driver can see that they are driving through what used to be a neighborhood. In many European cities, for example, highways limit access to and bypass the central parts of cities. New Urbanists argue that density is needed to make an urban economy productive, and by spreading people and activities over greater distances, highways undermine this productivity.

Smart transportation calls for trains that connect cities and neighborhoods, and pedestrian-friendly design that allows for a walkable community. New Ubanists recommend that a solution to the problems caused by being too dependent on autos as a mode of transportation is rebuilding existing cities and densifying existing suburbs into compact, walkable cities connected by an extensive train system. Trains can solve many congestion problems that cities face; for example, a six-car train can carry as many people as 100 city blocks of moving cars.

Chicago's downtown public transit options are numerous. The Chicago transportation system was built during a time (1870s) when downtown Chicago was the focus of business, shopping, services, and it made sense that all trains would come to a central point in the city. CTA is often in the news due to management issues and budget problems and is continually asking state government for more funding, yet riders do not see any improvements in their daily commute. 
Three years ago, Mayor Daley began to resurrect his father's plan of building a Cross-town Expressway. The vision has been to create a mini-Cross-town for trucks only to help divert trucks that now clog Chicago's expressways. A bus lane or rapid-transit line has also been part of the picture. In August 2005, the City announced that consultants are working out many of the logistics of this plan. The City proposed five mass-transit alternatives along what is known as the Mid-City Line (an area that stretches from Jefferson Park to Ford City). The most popular alternative (with a projected 95,280 riders per day) would be a bus rapid-transit line between River Road and $95^{\text {th }}$ Street (Chicago Sun Times [8]). This would run along railroad right-of-way and surface streets using an intelligent transportation system to change traffic lights to green as buses approach. This type of system helps buses quickly get through traffic and avoid congestion. The City has yet to address construction costs, residential displacement or fares for such a system, however, it is promising that the Mayor is addressing existing congestion and transportation issues that face the City on a daily basis.

When cities begin to think about functional types of transportation, they are taking a step toward creating opportunities for economic and social development and thus will create more livable communities.

\section{Greening}

New Urbanism has helped put an emphasis on environmentally-sensitive construction as part of the walkable, livable communities that the NU principles recommend.

The U.S. Green Building Council, a coalition that promotes environmentallysound building construction and practices, devised a building standard called LEED (Leadership in Energy and Environmental Design) that building developers and managers can work toward achieving as part of new and existing developments (USGBC [9]). LEED is voluntary and offers a set of guidelines to help develop and rehab buildings so they are designed to last and perform better than non-LEED certified buildings.

Green office and living facilities are built with more recycled materials and tend to be more visually appealing. These buildings also tend to be more costeffective in the use of utilities such as water and electricity. Studies have shown that green office buildings bolster worker productivity and employers whose offices are green promote that their employees are happier and healthier working in a green environment. This New Urbanism principle of a sustainable environment (sustainability) is another example of New Urbanism creating economic and social opportunity.

Mayor Daley is working toward increasing the number of green commercial and residential buildings throughout the city. He built the first municipal rooftop garden on City Hall and opened one of only five LEED Platinum-certified buildings in the country: The Chicago Center for Green Technology located at 445 North Sacramento Boulevard. This center uses solar and geothermal energy, has a rooftop garden, and a natural habitat to filter storm water. More city 
buildings are planned to be LEED- certified, including libraries, fire stations, and a refueling station for the city's fleet of natural-gas vehicles.

Mayor Daley was named the 2005 Design Patron by the Smithsonian Institution's Cooper-Hewitt National Design Museum in New York. He was recognized for his efforts over the past 16 years to "transform Chicago into a green city, planting 400,000 trees and beginning an effort to attract renewableenergy companies" (Daniels [10]). On November 8, 2005, Mayor Daley received an award from The Nature Museum and The Chicago Academy of Sciences in recognition of his commitment to making Chicago a green city.

Chicago sets an example that building sustainable communities and attracting green businesses makes economic and social sense.

\section{Conclusion}

Chicago, like many other urban centers, is in a constant state of development and redevelopment.

Throughout multiple neighborhoods and sections of Chicago, Quality Architecture \& Urban Design is represented. This principle emphasizes beauty, aesthetics, human comfort, and a sense of place. Millennium Park is a good example of this and it presents civic-use space for the community in the form of concert space, a garden, and the park itself.

Another New Urbanism principle that Chicago is incorporating and recognizing the importance of is Sustainability. Aside from greening (which Chicago is doing quite well), sustainability refers to producing more in a local environment and this includes local businesses. One way that this is being addressed in Chicago is via the Local First campaign. Local First works with local business owners to promote buying local and will encourage consumers to buy, for example, their morning coffee at a locally-owned café or to buy reading material at a woman-owned bookstore rather than big-box name. This will lead to economic growth and job creation through the vehicle of local purchasing in Chicago.

The City cannot tout that it is a center of New Urbanism. Critics of Chicago could point out that the city is not walkable, it is not connected in a manner that eases traffic congestion, it lacks a large number of mixed-use developments, mixed housing is not part of every neighborhood, and smart transportation is something that needs more attention.

In a time when urban landscape is being changed by nature and human nature, there is a recognized need in the U.S. for New Urbanism.

The question of New Urbanism is not, smart growth vs. no growth. Rather, it is smart growth vs. sprawl. All cities and towns start out with lower densities, and eventually evolve into denser places to accommodate growing populations. The only alternative is to grow endlessly outward and that can destroy a region's quality of life as it consumes farmland and wilderness, creates very high levels of vehicle use, and moves homes further and further from jobs, schools, and parks. 
The sustainability of our cities, towns, businesses, and lifestyles is dependent upon how we use our existing resources today and this will determine the future. New Urbanism presents a sustainable way of designing and living that will ensure we have resources, homes, and businesses today and tomorrow.

\section{References}

[1] The Ed Bacon Foundation, www.edbacon.com.

[2] Victoria Transport Policy Institute, www.vtpi.org/tdm/tdm116.htm.

[3] CTA Overview, Chicago Transit Authority, www.transitchicago.com.

[4] New Urbanism, www.newurbanism.org.

[5] Norquist, John, The Wealth of Cities, Perseus Books, Cambridge, 1998.

[6] City Journal, www.city-journal.org.

[7] Spinney, Robert G., City of Big Shoulders: A History of Chicago, Northern Illinois Press, DeKalb, 2000.

[8] Herrmann, Andres, "Searching to reclaim the city's inner soul", Chicago Sun Times, August 26, 2005.

[9] United States Green Building Council. LEED, Washington DC, www.usgbc.org.

[10] Daniels, Mary, "The jolly green mayor", Chicago Tribune, October 30, 2005. 